\title{
Micropropagation and Screening of Phytocompounds Present among in vitro Raised and Wild Plants of Rauvolfia serpentine
}

\author{
Varnika $^{1}$, Rohit SHARMA ${ }^{2}$, Ajay SINGH ${ }^{3}$, Shalini $^{4}$ and Nishesh SHARMA ${ }^{2, *}$ \\ ${ }^{1}$ Uttarakhand Technical University, Dehradun, India \\ ${ }^{2}$ Department of Biotechnology, School of Applied \& Lifesciences, Uttaranchal University, \\ Dehradun, India \\ ${ }^{3}$ Department of Chemistry, School of Applied \& Lifesciences, Uttaranchal University, Dehradun, India \\ ${ }^{4}$ Department of Biotechnology, Dolphin $(P G)$ College of Science \& Agriculture, Dehradun, India
}

("Corresponding author's e-mail: nishesh21@gmail.com)

Received: 4 March 2019, Revised: 17 June 2020, Accepted: 19 July 2020

\begin{abstract}
Rauvolfia serpentina, commonly known as Sarpgandha, is a plant well-known for being utilized for several medicinal purposes. Unrestricted collection from natural stands and overexploitation for medicinal and traditional purposes have rendered it endangered, hence there is necessary requirement for the development of cultivation protocols for mass propagation and sustained utilization of the plant. In the present study, in vitro culture of the apical parts of $R$. serpentina on MS (Murashige and Skoog) medium enriched with NAA resulted in development of callus, whereas multiple shoot regeneration along with callus development was achieved on medium combination MS + NAA + Kn and MS + NAA + BAP. MS $+4 \mu \mathrm{M}$ NAA $+4 \mu \mathrm{M}$ BAP was found to be most optimum media composition for regeneration of shoots and callus. Among different media combinations utilized for in vitro rooting, a maximum of $82.6 \%$ explants developed in vitro roots on $1 / 2 \mathrm{MS}+12 \mu \mathrm{M}$ NAA. Gas chromatography-mass spectrometry (GCMS) analysis of methanolic extract prepared from leaves of wild and micropropagated plants of $R$. serpentina revealed the presence of 38 and 48 phytocompounds, respectively. 9, 12-Octadecadienoic acid, Methyl linoleate, Methyl stearate, Hexadecanoic acid, methyl ester, Linoleic acid, Ergost-4, 7, and 22trien-3.alpha.-ol were some of the major compounds found to be present in the leaves of wild plants, and Linoleic acid, methyl ester, Cis-Linoleic Acid Methyl Ester, Methyl elaidate, hexadecanoic acid, and methyl ester were major compounds found to be present in in vitro raised plants. Many of the compounds detected have been known to possess 1 or more biological or pharmacological activities.
\end{abstract}

Keywords: Rauvolfia serpentine, Conservation, Apical part, Phytochemical analysis

\section{Introduction}

Rauvolfia serpentina (L) Benth. Ex. Kurz is a well known medicinal plant and has been utilized for medicinal purposes in the Ayurvedic system of medicine for a long time [1,2]. R. serpentina is commonly known as Sarpgandha and is a perennial evergreen shrub. The plant is found in India, China, Indonesia, Pakistan, Nepal, Malaysia, and Sri Lanka. R. serpentine is known to inhabit regions with an annual rainfall of $200-250 \mathrm{~cm}$, along with an altitude of $1,000 \mathrm{~m}$. The plant possesses several biological and pharmacological activities including lowering of blood pressure, controlling fever, stimulation of uterine contraction, treating anxiety, insomnia and dyspepsia, and has hypolipidemic, antihypertensive, and antidiabetic activities [3]. The plant is specifically utilized against snake and scorpion bites [1,4-6]. The plant is also reported to possess antifungal and antimicrobial activities [7]. Several bioactive 
http://wjst.wu.ac.th

phytocompounds have been reported to be present in $R$. serpentine including flavonoids, alkaloids, glycosides, tannins, etc. Reserpine, ajmalicine, serpentine, yohimbine, deserpidine, and ajmaline constitute different bioactive compounds identified and characterized to possess biological activities [8]. Reserpine, by far, remains the most commonly utilized phytocompound obtained from $R$. serpentine for medicinal purposes $[9,10]$.

Overexploitation for medicinal purposes, poor rate of germination, destruction of habitat, and inadequate commercial cultivation have, together, made the plant endangered [11-13]. R. serpentine is a "red" listed plant in India and has been listed as an endangered plant by the International Union for Conservation of Nature (IUCN) [14,15]. Hence, there is an urgent requirement for the development of procedures and strategies for the conservation and mass propagation of this endangered species. Considering the present status of the plant, studies needs to be conducted that are applicable not only for propagating the plant at a laboratory level but which can simultaneously be utilized for rehabilitation of the plant in wild stands. The present study reports an effective and rapid method for mass propagation through in vitro culture of the apical parts of $R$. serpentina. Also, mother and in vitro regenerated plants were subjected to GC-MS analysis to bring out a comparative account of phytocompounds produced in wild and micropropagated plants.

\section{Materials and methods}

\section{Explants}

For the present study, plants of Rauwolfia serpentina (Figure 1a) were procured from the medicinal garden, Patanjali Roorkee, and were authenticated by Dr. Manjul Dhiman, Head of the Department of Botany, Kanahiya Lal DAV (PG) College, Roorkee, India. Apical parts (approximately $1.5-2 \mathrm{~cm}$ from the tip, possessing meristematic tissue) obtained from mature plants were utilized as explants.

\section{Sterilization of explants}

Apical parts were thoroughly washed with running tap water for approximately $10 \mathrm{~min}$ to remove any external impurities attached. Explants were then transferred to a beaker containing $1 \%$ solution of Tween 20 for about 5 min with constant stirring, after which explants were again washed with water to remove all traces of detergent. Treatment of the fungicide Bavastin was given for about 3 min, following which the explants were washed with distilled water. Explants were then rinsed with $70 \%$ ethanol for about 45 - $60 \mathrm{sec}$ and washed with distilled water. After treatment with $70 \%$ ethanol, explants were surface sterilized with $0.1 \% \mathrm{HgCl}_{2}$ for about 3 min under aseptic conditions in laminar air flow. After sterilization, explants were washed at least 3 times with sterile distilled water to remove all traces of $\mathrm{HgCl}_{2}$, dried using sterile Whatman paper, excised to appropriate size, and inoculated onto culture medium.

\section{Establishment of cultures}

Sterilized apical parts were inoculated on MS (Murashige and Skoog) media [16] fortified with different concentrations of 1-Naphthaleneacetic acid (NAA) $(2,4,8$ and $10 \mu \mathrm{M})$ alone or in combination with varying concentrations of Kinetin $(\mathrm{Kn})(2,4$ and $8 \mu \mathrm{M})$ or 6-Benzylaminopurine (BAP) $(2,4$ and 8 $\mu \mathrm{M})$. Cultures were incubated at $25 \pm 2{ }^{\circ} \mathrm{C}$ with $16 \mathrm{~h}$ photoperiod of light $\left(15 \mathrm{uE} / \mathrm{m}^{2} / \mathrm{s}\right.$ irradiance $)$. Each experimental setup comprised at least 20 cultures, and each experiment was repeated twice in case microbial contamination occurring in the cultures was less than $10 \%$; however, in any experimental setup, if bacterial or fungal contamination occurred in more than $10 \%$ of cultures, an additional set of the experiment was performed so as to possess an adequate number of replicates of each medium combination. Each experimental setup was supplemented with a control treatment comprising hormonefree media. 
http://wjst.wu.ac.th

\section{In vitro rooting}

Well elongated shoots were aseptically transferred to rooting media. MS+NAA (4, 8 and $12 \mu \mathrm{M})$; MS + IAA (4, 8 and $12 \mu \mathrm{M})$; MS + IBA $(4,8$ and $12 \mu \mathrm{M})$ were the 3 culture media utilized for development of in vitro roots. Both full and half strength media were employed in an independent set of experiments for each concentration of NAA, IAA (Indole-3-acetic acid), and Indole-3-butyric acid (IBA) (Table 2). Each experimental setup was supplemented with a control treatment comprising hormone-free media.

\section{Acclimatization}

Plants with well-developed shoots and roots were carefully removed from the culture vessel under aseptic conditions [17]. Roots of the plants were gently washed with sterile water so as to remove any media particles attached to the roots. Each plant was individually transferred to plastic pots (with an approximate size of $5^{\prime \prime} \times 5^{\prime \prime} \times 8^{\prime \prime}(\mathrm{L} \times \mathrm{B} \times \mathrm{H})$ which were filled $(1 / 3$ volume $)$ with autoclaved sand and soil in a ratio of $1: 1$. Pots were covered with transparent poly bags and incubated under similar conditions utilized for in vitro culture (Figures $1 \mathbf{N}$ and 10). Pots were irrigated with a solution having $1 / 4$ strength MS nutrients to keep the soil sufficiently moist. After about 10 days a minor incision was made onto the polybags. After a period of another 15 days, when new leaves began to emerge, the polybags were completely removed, and pots were transferred to glass chambers. Plants exhibiting normal growth were transferred to natural conditions.

\section{Recording of data and statistical analysis}

Cultures were regularly monitored for any morphological changes or growth. Observations made were analyzed to evaluate the percentage of cultures exhibiting in vitro response on each media combination. Results were subjected to Duncan's Multiple Range Test (DMRT) so as to evaluate the significance of respective media combinations.

\section{GC-MS analysis}

Methanolic extract prepared from dry leaf powder of leaves obtained from mother and in vitro regenerated plants were subjected to GC-MS analysis. The plant powder was extracted with methanol using Soxhlet apparatus. GC-MS analysis was done through a Perkin Elmer Auto System XL GC-MS analyzer, which utilized an electron ionization energy system with ionization energy of $70 \mathrm{eV}$ for detection of compounds present in an extract. Helium gas $(99.999 \%)$ served as a carrier with a constant flow rate of $1.51 \mathrm{ml} / \mathrm{min}$, and an injection volume of $2 \mu \mathrm{l}$ was employed. Software used, adapted to handle mass spectra and chromatograms was Turbo Mass. Identification of phytocompounds was based on the respective molecular structure and molecular mass and on direct comparison of retention times and mass spectral data with those for standard compounds and computer matching with the library (Wiley library, database NIST 98, NIST data bank). The relative percentage amount of each component was calculated by comparing the average peak area to the total areas. Once identified, the phytocompounds were searched for their documented and reported biological and pharmacological properties and medicinal values.

\section{Results and discussion}

Regeneration from apical parts of $R$. serpentina

In vitro culture of the apical parts onto hormone-free (control) media resulted in negligible growth, with a maximum of $44.6 \%$ cultures exhibiting marginal enlargement of explants and induction of growth (Figure 1B). However, the apical parts failed to exhibit further growth and proliferation. In vitro culture of apical parts onto MS + NAA $(2-8 \mu \mathrm{M})$ resulted in the development of callus on all concentrations of NAA. A moderate extent of callusing (Figures 1C and 1D) was attained onto lower concentration of NAA $(2$ and $4 \mu \mathrm{M}$ ), and maximum proliferation of callus was achieved onto MS $+8 \mu \mathrm{M}$ NAA. 
Regeneration of thin fibrous whitish roots was achieved on all media combinations, irrespective of concentration of NAA. Callus obtained was fragile in nature and creamish or green in color. When apical parts were cultured onto MS media fortified with different concentrations of $\mathrm{Kn}$ and NAA, regeneration of callus along with shoot bud induction was attained (Figure 1F). All the cultures exhibited callus regeneration, with callus developing predominantly from the basal part of explants present in direct contact with media. Percentage of explants developing shoot buds varied depending upon concentration of PGRs present in the medium, with a maximum of $88.8 \%$ cultures developing shoots onto medium combination MS $+8 \mu \mathrm{MKn}+8 \mu \mathrm{M}$ NAA. On average, about $2.4 \pm 0.2$ shoots, with a maximum of 5 shoots, developed onto this medium combination. Extensive proliferation of callus and regeneration of adventitious roots from callus was attained after about 3 weeks of induction of callus (Figure 1J). Regenerated roots were thin and fibrous onto media combinations containing lower NAA concentrations $(2-4 \mu \mathrm{M})$; however, thick roots were obtained on media containing higher NAA concentrations $(8-10$ $\mu \mathrm{M})$.

In vitro culture of apical parts onto $\mathrm{MS}+\mathrm{BAP}(2-8 \mu \mathrm{M})+\mathrm{NAA}(2-10 \mu \mathrm{M})$ also resulted in shoot bud induction, callus development, and regeneration of roots from callus. With an increase in the concentration of BAP, a simultaneous increase in number of regenerated shoots was achieved. On average, $4.4 \pm 0.2$ shoots were obtained on medium combination MS $+8 \mu \mathrm{M}$ BAP $+4 \mu \mathrm{M}$ NAA (Figure 1G), with a maximum regeneration of 7 shoots. Extensive callus development was achieved on all media combinations. BAP supplemented media were found to be more effective for the proliferation of in vitro developed callus as compared to Kn supplemented media. Callus obtained were greenish brown (Figure 1E). Several roots originated from the callus; some of the roots became thick and eventually spread throughout the culture media. In vitro regenerated shoots exhibited enhanced elongation and multiple shoot regeneration when transferred onto MS media with low BAP $(2-4 \mu \mathrm{M})$ concentrations (Figures 1H and 1I). Regenerated shoots when subcultured onto basal medium also exhibited elongation (Figure 1K and 1L), Rajasekharan [18] also achieved proliferation of shoots from axillary meristem of $R$. serpentina on MS medium supplemented with IBA and NAA. Rani et al. [1] reported axillary shoots of $R$. serpentina exhibited regeneration of maximum number of shoots on MS medium containing IAA and BAP. In another micropropagation study conducted by Khan et al. [19] on R. serpentina, MS + BAP + NAA was found to be effective enough to induce direct regeneration of shoots from nodal segments and development of callus, followed by shoot regeneration from in vitro cultured leaf segments. In their study, regeneration from nodal and leaf segments was also achieved on MS + BAP + Kn and MS + BAP + IAA. Callus regeneration from nodal segments of $R$. serpentina were also reported [20] on $\mathrm{MS}+0.5 \mathrm{mg} / \mathrm{l} \mathrm{BA}+$ $2 \mathrm{mg} / 1$ IAA. Ilahi et al. [21] reported the development of callus along with the regeneration of meristemoid structures from nodal segments of $R$. serpentina onto MS $+2 \mathrm{mg} / 1 \mathrm{BAP}+1 \mathrm{mg} / 1 \mathrm{IAA}$.

Table 1 Effect of different PGRs on in vitro culture of apical parts of $R$. serpentine.

\begin{tabular}{|c|c|c|c|c|c|c|}
\hline \multicolumn{2}{|c|}{$\begin{array}{c}\text { Plant growth } \\
\text { regulator }(\boldsymbol{\mu M})\end{array}$} & $\begin{array}{l}\text { \% cultures } \\
\text { developing } \\
\text { shoots }\end{array}$ & $\begin{array}{l}\text { Avg. no. of } \\
\text { shoots }\end{array}$ & $\begin{array}{c}\text { Maximum } \\
\text { no. of shoots }\end{array}$ & $\begin{array}{l}\text { Degree of } \\
\text { callusing }\end{array}$ & $\begin{array}{l}\text { Nature of } \\
\text { callus }\end{array}$ \\
\hline \multicolumn{7}{|l|}{ NAA } \\
\hline 2 & & - & - & - & ++ & \multirow{4}{*}{$\begin{array}{c}\text { Creamish } \\
\text { fragile } \\
\text { Green fragile }\end{array}$} \\
\hline 4 & & - & - & - & ++ & \\
\hline 8 & & - & - & - & ++++ & \\
\hline 10 & & - & - & - & +++ & \\
\hline \multicolumn{7}{|c|}{ NAA $\quad$ Kn } \\
\hline 2 & 2 & 46.4 & $1.4 \pm 0.2^{\mathrm{d}}$ & 3 & ++ & \multirow{3}{*}{$\begin{array}{c}\text { Crystalline } \\
\text { white compact }\end{array}$} \\
\hline 2 & 4 & 48.0 & $1.2 \pm 0.4^{\mathrm{e}}$ & 3 & ++ & \\
\hline 2 & 8 & 52.8 & $2.4 \pm 0.2^{\mathrm{b}}$ & 5 & ++ & \\
\hline
\end{tabular}




\begin{tabular}{|c|c|c|c|c|c|c|}
\hline \multicolumn{2}{|c|}{$\begin{array}{c}\text { Plant growth } \\
\text { regulator }(\mu \mathrm{M})\end{array}$} & \multirow{2}{*}{$\begin{array}{c}\begin{array}{c}\text { \% cultures } \\
\text { developing } \\
\text { shoots }\end{array} \\
56.4\end{array}$} & \multirow{2}{*}{$\begin{array}{c}\begin{array}{c}\text { Avg. no. of } \\
\text { shoots }\end{array} \\
1.2 \pm 0.2^{\mathrm{e}}\end{array}$} & \multirow{2}{*}{$\begin{array}{c}\begin{array}{c}\text { Maximum } \\
\text { no. of shoots }\end{array} \\
3\end{array}$} & \multirow{2}{*}{$\begin{array}{c}\begin{array}{c}\text { Degree of } \\
\text { callusing }\end{array} \\
++++\end{array}$} & \multirow[t]{2}{*}{$\begin{array}{l}\text { Nature of } \\
\text { callus }\end{array}$} \\
\hline 4 & 2 & & & & & \\
\hline 4 & 4 & 68.4 & $2.4 \pm 0.2^{\mathrm{b}}$ & 5 & +++ & \multirow{3}{*}{$\begin{array}{l}\text { Crystalline } \\
\text { white fragile }\end{array}$} \\
\hline 4 & 8 & 68.2 & $1.4 \pm 0.2^{\mathrm{d}}$ & 5 & +++ & \\
\hline 8 & 2 & 58.6 & $1.6 \pm 0.2^{\mathrm{c}}$ & 4 & ++++ & \\
\hline 8 & 4 & 70.5 & $2.8 \pm 0.2^{\mathrm{a}}$ & 5 & +++ & \multirow[t]{2}{*}{ Green fragile } \\
\hline 8 & 8 & 88.4 & $2.4 \pm 0.2^{\mathrm{b}}$ & 5 & ++++ & \\
\hline NAA & BAP & & & & & \\
\hline 2 & 2 & 62.8 & $1.9 \pm 0.2^{\mathrm{h}}$ & 5 & ++ & \multirow{7}{*}{$\begin{array}{l}\text { Crystalline } \\
\text { white fragile }\end{array}$} \\
\hline 2 & 4 & 100 & $2.6 \pm 0.2^{\mathrm{e}}$ & 6 & +++ & \\
\hline 2 & 8 & 100 & $3.2 \pm 0.4^{\mathrm{d}}$ & 6 & +++ & \\
\hline 4 & 2 & 70.0 & $2.3 \pm 0.6^{\mathrm{fg}}$ & 5 & +++ & \\
\hline 4 & 4 & 100 & $4.0 \pm 0.5^{\mathrm{b}}$ & 8 & ++++ & \\
\hline 4 & 8 & 100 & $4.4 \pm 0.2^{\mathrm{a}}$ & 7 & ++++ & \\
\hline 8 & 2 & 76.4 & $2.4 \pm 1.2^{\mathrm{fg}}$ & 5 & +++ & \\
\hline 8 & 4 & 100 & $3.2 \pm 0.2^{\mathrm{d}}$ & 6 & ++++ & \multirow{2}{*}{$\begin{array}{c}\text { Green } \\
\text { crystalline }\end{array}$} \\
\hline 8 & 8 & 100 & $3.4 \pm 0.4 \mathrm{c}$ & 6 & ++++ & \\
\hline
\end{tabular}

- NAA (Naphthalene acetic acid), Kn (Kinetin), BAP (Benzyl aminopurine).

- Values are means of 3 replicates. Mean values followed by same letters are not significantly different at $\mathrm{p} \geq 0.05$ DMRT.

$\bullet++$ (Moderate callusing), +++ (Good callusing), ++++ (Extensive callusing)

\section{In vitro rooting}

Earlier studies achieved in vitro rooting from regenerated shoots of $R$. serpentina onto MS medium containing either NAA and IAA or NAA and IBA. In the present study, comparative analysis of 3 auxins was conducted so as to evaluate their efficacy to induce the formation of in vitro roots. One of the most prominent findings was enhanced in vitro rooting onto half strength MS medium as compared to full strength. An earlier study conducted by the authors [13] also reported half MS medium to be far superior than full strength medium for the development of in vitro roots in $R$. serpentina. Besides $R$. serpentina, several studies conducted on other plant species have also implicated enhanced efficiency of $1 / 2$ strength MS medium to induce development of in vitro roots as compared to full strength medium. Among the different PGR utilized, NAA was found to be the most appropriate for the development and proliferation of roots from regenerated shoots.

In the present study, $38.4 \%$ of explants developed in vitro roots on MS $+4 \mu \mathrm{M}$ NAA, with an average number of $3.4 \pm 1.2$ roots per explants. When the strength of the medium was reduced to half with the same concentration of NAA, in vitro rooting was achieved in $58.4 \%$ of cultures, with an average and maximum number of roots being $3.8 \pm 0.2$ and 5 , respectively. On increasing the concentration of NAA to $8 \mu \mathrm{M}$, in vitro rooting was achieved in 42.8 and $72.8 \%$ of cultures onto full and half strength medium, respectively. Average and maximum number of roots onto $1 / 2 \mathrm{MS}+8 \mu \mathrm{M}$ NAA were $4.2 \pm 0.6$ and 8 , respectively. When the concentration of NAA was further increased to $12 \mu \mathrm{M}, 68.6 \%$ of cultures developed roots on full strength medium and $82.6 \%$ of cultures exhibited development of roots onto half strength medium. In another study [13], in vitro rooting was achieved in about $88.6 \%$ of cultures onto $\mathrm{MS}+20 \mu \mathrm{M}$ NAA. The roots obtained in the present study exhibited limited branching (Figure 1M), which supported the easy handling of regenerated plants while removing media attached to roots before acclimatization. 
http://wjst.wu.ac.th

When IAA was utilized as a rooting hormone, $42 \%$ of cultures developed roots onto MS $+4 \mu \mathrm{M}$ IAA. The rooting response was enhanced to $48.4 \%$ when the strength of the medium was reduced to half. Onto higher concentration of IAA $(8 \mu \mathrm{M}), 44.8$ and $66 \%$ of cultures exhibited in vitro rooting onto full and half strength medium, respectively. Average and maximum number of roots onto half MS $+8 \mu \mathrm{M}$ IAA were $4.2 \pm 0.6$ and 8 , respectively. On further increasing the concentration of IAA to $12 \mu \mathrm{M}$, the overall percentage of cultures developing roots were enhanced to $58.2 \%$ onto full strength medium and $74.2 \%$ onto half strength medium.

In full strength MS medium enriched with $4 \mu \mathrm{M}$ IBA, about $32.4 \%$ cultures developed in vitro roots, with an average number of $3 \pm 0.6$ roots per explant. On reducing the strength of medium to half, in vitro rooting was achieved in $52 \%$ when the concentration of IBA was enhanced to $12 \mu \mathrm{M}$, and a maximum of 62.6 and 72.6 cultures developed in vitro roots onto full and half strength medium, respectively. Average and maximum number of roots onto half MS $+12 \mu \mathrm{M}$ IBA were $5.6 \pm 0.4$ and 8 , respectively. Earlier studies $[4,12]$ achieved development of in vitro roots onto IBA supplemented MS medium. In another study [22], in vitro rooting was achieved in $72 \%$ of cultures onto MS $+25 \mu \mathrm{M} \mathrm{IBA}$, with an average number of $6.0 \pm 0.6$ roots per explant. Medium containing both IBA and IAA has also been reported to be a suitable medium for development of in vitro roots in $R$. serpentine [23]. A maximum of $62.4 \%$ in vitro regenerated plants survived during the process of transplantation and exhibited normal growth and development.

Table 2 In vitro rooting from regenerated shoots of $R$. serpentine.

\begin{tabular}{|c|c|c|c|c|}
\hline MS & PGR & $\begin{array}{c}\% \text { Culture } \\
\text { developing roots }\end{array}$ & $\begin{array}{l}\text { Avg. no. } \\
\text { of roots }\end{array}$ & $\begin{array}{c}\text { Max. no. } \\
\text { of roots }\end{array}$ \\
\hline \multirow{10}{*}{ 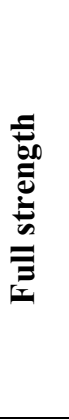 } & Control & - & - & - \\
\hline & $4 \mu \mathrm{M}$ NAA & 38.4 & $3.4 \pm 1.2^{\mathrm{j}}$ & 05 \\
\hline & $8 \mu \mathrm{M}$ NAA & 42.8 & $3.2 \pm 0.4^{\mathrm{k}}$ & 04 \\
\hline & $12 \mu \mathrm{M}$ NAA & 68.6 & $2.8 \pm 0.6^{1}$ & 04 \\
\hline & $4 \mu \mathrm{M}$ IAA & 42.0 & $3.6 \pm 1.2^{\mathrm{i}}$ & 05 \\
\hline & $8 \mu \mathrm{M}$ IAA & 44.8 & $3.8 \pm 0.6^{\mathrm{h}}$ & 06 \\
\hline & $12 \mu \mathrm{M}$ IAA & 58.2 & $4.8 \pm 0.4^{\mathrm{e}}$ & 06 \\
\hline & $4 \mu \mathrm{M}$ IBA & 32.4 & $3.2 \pm 0.6^{\mathrm{k}}$ & 05 \\
\hline & $8 \mu \mathrm{M}$ IBA & 38.8 & $4.2 \pm 0.2^{\mathrm{f}}$ & 07 \\
\hline & $12 \mu \mathrm{M}$ IBA & 62.6 & $4.0 \pm 0.6^{\mathrm{g}}$ & 06 \\
\hline \multirow{10}{*}{ 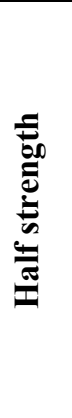 } & Control & 06.4 & $1.4 \pm 0.2^{\mathrm{i}}$ & 02 \\
\hline & $4 \mu \mathrm{M}$ NAA & 58.4 & $3.8 \pm 0.2^{\mathrm{h}}$ & 05 \\
\hline & $8 \mu \mathrm{M}$ NAA & 72.8 & $4.2 \pm 0.6^{\mathrm{f}}$ & 08 \\
\hline & $12 \mu \mathrm{M}$ NAA & 82.6 & $6.0 \pm 0.4^{\mathrm{a}}$ & 09 \\
\hline & $4 \mu \mathrm{M}$ IAA & 48.4 & $4.0 \pm 0.2^{\mathrm{g}}$ & 07 \\
\hline & $8 \mu \mathrm{M}$ IAA & 66.0 & $5.2 \pm 0.4^{\mathrm{d}}$ & 08 \\
\hline & $12 \mu \mathrm{M}$ IAA & 74.2 & $4.8 \pm 1.2^{\mathrm{e}}$ & 07 \\
\hline & $4 \mu \mathrm{M}$ IBA & 52.0 & $5.2 \pm 0.4^{\mathrm{d}}$ & 08 \\
\hline & $8 \mu \mathrm{M}$ IBA & 62.8 & $5.4 \pm 0.4^{\mathrm{c}}$ & 09 \\
\hline & $12 \mu \mathrm{M}$ IBA & 72.6 & $5.6 \pm 0.4^{b}$ & 08 \\
\hline
\end{tabular}

- NAA (Naphthaline acetic acid), IAA (Indole butyric acid), IBA (Indole butyric acid).

- Values are means of 3 replicates. Mean values followed by same letters are not significantly different at $\mathrm{p} \geq 0.05$ DMRT 
http://wjst.wu.ac.th
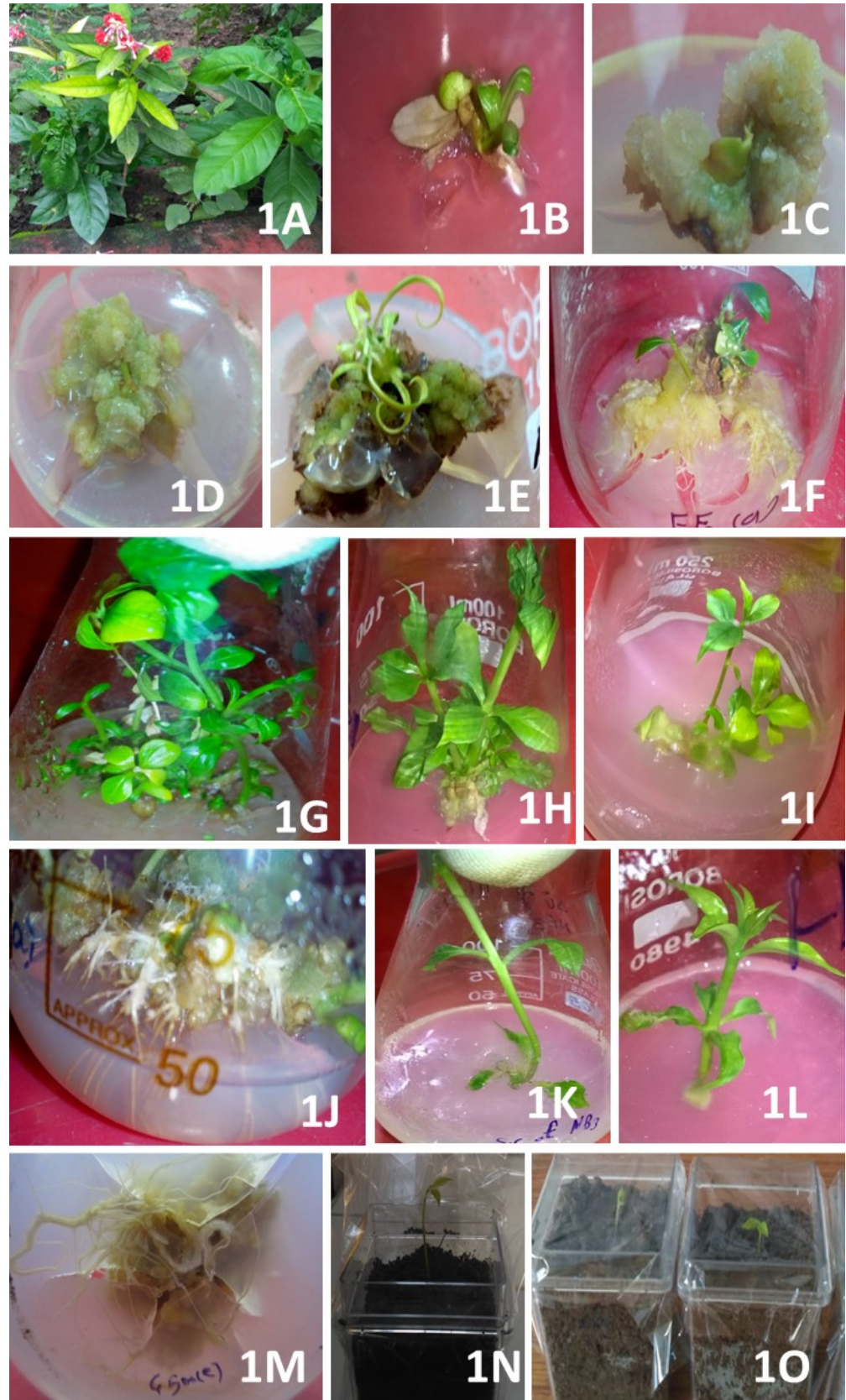

Figure 1A-Mature plant of $R$. serpentina; B-Induction of growth (no further proliferation) on hormonefree medium; C, D-Moderate extent of callusing onto lower concentration of NAA 2 and $4 \mu \mathrm{M}$ respectively; E-Regeneration of callus and shoot bud induction on MS + Kn + NAA; F-Callus and shoot bud induction on MS + BAP + Kn; G-Multiple shoot regeneration on MS $+8 \mu \mathrm{M}$ BAP $+4 \mu \mathrm{M}$ NAA; $\mathbf{H}$, I-Enhanced elongation and multiple shoot regeneration from subculture of regenerated shoots onto MS medium with low BAP $(2-4 \mu \mathrm{M})$ concentration; J-Extensive proliferation of callus and regeneration of adventitious roots from callus on MS $+8 \mu \mathrm{MKn}+8 \mu \mathrm{M}$ NAA; $\mathbf{K}$, L-Elongation of shoots onto basal medium; M-In vitro rooting on MS $+20 \mu \mathrm{M} \mathrm{NAA} ; \mathbf{N}, \mathbf{O}$-In vitro regenerated plants under the process of acclimatization. 


\section{GC-MS analysis of leaves of micropropagated and mother plants of $R$. serpentina}

Methanolic extract of leaves of the mother plant and in vitro regenerated plant when subjected to GC-MS analysis revealed the presence of a range of phytocompounds. A total of 38 compounds were found to be present in methanolic extract prepared from the leaves of the mother plant (Table 3, Figure 2), among which the major compounds found to be present were linoleic acid (24.42\%), 9, 10 octadecadienoic acid (20.4\%), 9 - 10 octadecanoic acid methyl ester (14.11\%), and hexadecanoic acid methyl ester $(7.03 \%)$. Similarly, the presence of 41 phytocompounds were detected in the methanolic extract of the leaves of a micropropagated plant (Table 4, Figure 3) of $R$. serpentine. Figures 4 and 5 depicts mass spectra of some of the compounds identified through GC-MS in the leaves of the mother plant and the micropropagated plant, respectively. Major compounds found to be present include Cislinoleic acid methyl ester $(24.35 \%)$, methyl elaidate $(15.34 \%)$, linoleic acid $(15.28 \%)$, hexadecanoic acid, and methyl ester $(11.89 \%)$. Many of the compounds were found to be present in the mother as well as in the in vitro raised plant; these compounds include 1-pentadecanamine, n, n-dimethyl, hexadecanoic acid, methyl ester, methyl stearate, linoleic acid, Linoleoyl chloride, eicosanoic acid, methyl ester, 9, 12octadecadienoyl chloride, $(\mathrm{z}, \mathrm{z})-$, 15-hydroxypentadecanoic acid, cis-11-eicosenoic acid, methyl ester, glycidol stearate, docosanoic acid, methyl ester, Ethyl linoleate, tetracosanoic acid, methyl ester, ergost-4, 7, 22-trien-3.alpha.-ol, and Tridecanedial. However, a significant amount of variation was observed in their concentrations. The percentage of hexadecanoic acid methyl ester in the extract of the tissue cultured plant was $11.89 \%$, which decreased to $7.03 \%$ in the mother plant. Similarly, the percentage of linoleic acid in the micropropagated plant was found to be $15.28 \%$, which was enhanced to $24.42 \%$ in the extract of the mother plant. The percentage of tetracosanoic acid methyl ester in the extract of the micropropagated and the mother plants was found to be 0.15 and $0.31 \%$, respectively. In the micropropagated plant, the ethyl linoleate percentage was $2.43 \%$, which decreased to $0.21 \%$ in the mother plant. Besides these common phytocompounds, compounds including eiosane methyl elaidate, Bormyl chloride, and cholesteryl benzoate were found to be present only in the leaves of the micropropagated plant and were absent in the extract prepared from the leaves of mother plants. The presence of compounds of methyl linoleate, 1-glyceryl linoleate, and glycerol 2 palmitate was confined only to mother plants. Concentrations of compounds 9-hexadecenoic acid, methyl ester (z)-, linoleic acid, Linoleoyl chloride, 9-tricosene (z)-, glycidol stearate, 9, 12-octadecadienoyl chloride (z, z)-, tetracosanoic acid methyl ester, ergost-4, 7, 22-trien-3 alpha.-ol, and Tridecanedial were found to be higher in the extract of the mother plant as compared to their concentrations in the tissue cultured plants. On the contrary, concentrations of 1-pentadecanamine n, n-dimethyl, methyl stearate, Ethyl linoleate, cis-11eicosenoic acid, and methyl ester were found to be higher in extracts of leaves of micropropagated plants as compared to the mother plant. Another study [24] reported n-hexane extracts of roots of $R$. serpentine to possess 18 phyto compounds, among which cis-1, 3-dimethyl cyclohexane; 2 methyl pentane-2, 4-diol; 3 methyl heptan-2-ol; and 1, 1,2,3-tetramethylcyclopropane were the major compounds found to be present. In another study conducted by Sivaraman et al. [25], GC-MS analysis of ethanolic extracts of roots of $R$. serpentina was performed and the presence of 23 phytochemical compounds was reported. Phenol 1, 2, 4-bis (1, 1-dimethylethyl); Hexadecanoic acid 2-hydroxy-1-(hydroxyl methyl) ethyl ester; octadecanoic acid, 2, 3-dihydroxy propyl ester; and diethyl phthalate, eicosane comprised the major compounds found to be present in the extract. Most of the earlier studies conducted, pertaining to GC-MS analysis of $R$. serpentine, were restricted to the roots of the plant (owing to the immense medicinal potential of the roots); however, the present study reports the presence of phytocompounds with either medicinal properties or biological activities in the leaves of the plant as well. GC-MC analysis has been recognized as an extremely effective tool for screening or analyzing for the presence of various phytocompounds in different parts of plants. GC-MS analysis of an ethanolic extract of the roots of Coleus froshpotei revealed the presence of 19 phytocompounds [26]. Similarly, Patel et al. [27] reported 14 phytocompounds to be present in methanolic extracts of leaves of Terminalia coriacea. Rukshana et al. [28], in their study, analysed ethanolic extracts of leaves of Pergalaria daemia through GC-MS and 
http://wjst.wu.ac.th

found 15 phytocompounds to be present. Rautela et al. [29], in their study, implicated the types and number of phytocompounds to vary depending upon the solvent system utilized for preparing the plant extracts. In their study, 35 and 49 phytochemical compounds were reported to be present in methanolic and ethanolic extracts of leaves of Withania somnifera, respectively. The utility of GC-MS analysis becomes more pronounced in reference to plant tissue culture studies when considering comparative phytochemical analysis of micropropagated and wild plants. Sharma et al. [30], in their study on Withania coagulans, reported the presence of 44 and 56 phytocompounds to be present in methanolic extracts of leaves of wild and micropropagated plants, respectively. Karthikeyan and Sudan [31] also reported variation in a number of phytocompounds found to be present in in vitro cultured and in in vivo cultivated plants of Cleome gynandra.

Biological activities of phytocompounds found to be present in leaves of $R$. serpentine have been reported in the available literature [32-40]. Table 5 shows the pharmacological and biological activities of some of the phytocompounds identified in extracts of leaves of $R$. serpentine. Hence, the leaves of the plant can serve as efficient ingredients of medicinal preparations and be effectively utilized in the treatment of various diseases. Presently, the roots of $R$. serpentine are the part of the plant mainly utilized for medicinal purposes. However, the validation of leaves (extract) for their medicinal potential will not only provide an alternate source of raw material for medicinal formulation but, simultaneously, aid in the conservation of the species. Hence, further studies are recommended for evaluating the effective utilization of the leaves of $R$. serpentine in the treatment of specific diseases.

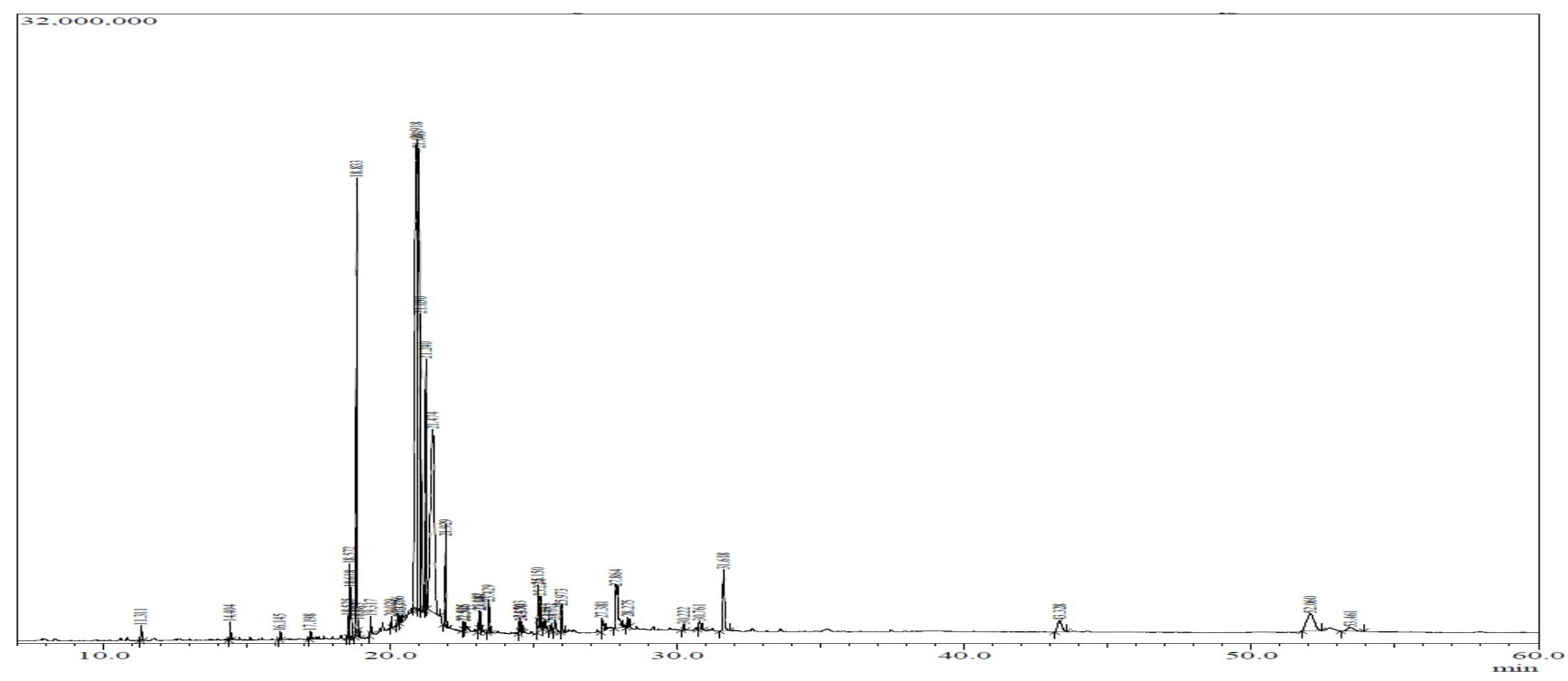

Figure 2 GC-MS analysis of methanolic extract of leaves of mother plant of $R$. serpentine. 
http://wjst.wu.ac.th

Table 3 GC-MS analysis of methanolic extract of leaves of mother plant of $R$. serpentine.

\begin{tabular}{|c|c|c|c|c|c|}
\hline Peak & R. time & $\begin{array}{c}\text { Area } \\
\%\end{array}$ & Name of compound & Mol formula & Mol weight \\
\hline 1 & 18.604 & 0.7 & 1-Pentadecanamine, N,N-dimethyl- & $\mathrm{C}_{17} \mathrm{H}_{37} \mathrm{~N}$ & 255 \\
\hline 2 & 18.797 & 7.03 & Hexadecanoic acid, methyl ester & $\mathrm{C}_{17} \mathrm{H}_{34} \mathrm{O}_{2}$ & 270 \\
\hline 3 & 19.274 & 0.41 & Pentadecanoic Acid & $\mathrm{C}_{15} \mathrm{H}_{30} \mathrm{O}_{2}$ & 242 \\
\hline 4 & 20.242 & 0.54 & Hexadecanoic acid, trimethylsilyl ester & $\mathrm{C}_{19} \mathrm{H}_{40} \mathrm{O}_{2} \mathrm{Si}$ & 328 \\
\hline 5 & 20.866 & 20.4 & 9,12-Octadecadienoic acid & $\mathrm{C}_{19} \mathrm{H}_{34} \mathrm{O}_{2}$ & 294 \\
\hline 6 & 20.943 & 14.11 & 9-Octadecenoic acid, methyl ester,(E)- & $\mathrm{C}_{19} \mathrm{H}_{36} \mathrm{O}_{2}$ & 296 \\
\hline 7 & 20.999 & 3.23 & Methyl linoleate & $\mathrm{C}_{19} \mathrm{H}_{34} \mathrm{O}_{2}$ & 294 \\
\hline 8 & 21.062 & 0.21 & Ethyl linoleate & $\mathrm{C}_{20} \mathrm{H}_{36} \mathrm{O}_{2}$ & 308 \\
\hline 9 & 21.209 & 3.49 & Methyl stearate & $\mathrm{C}_{19} \mathrm{H}_{38} \mathrm{O} 2$ & 298 \\
\hline 10 & 21.438 & 24.42 & Linoleic acid & $\mathrm{C}_{18} \mathrm{H}_{32} \mathrm{O}_{2}$ & 280 \\
\hline 11 & 21.91 & 1.23 & Methyl 10-trans,12-cis octadecadienoate & $\mathrm{C}_{19} \mathrm{H}_{34} \mathrm{O}_{2}$ & 294 \\
\hline 12 & 22.517 & 0.26 & Linoleoyl chloride & $\mathrm{C}_{18} \mathrm{H}_{31} \mathrm{ClO}$ & 298 \\
\hline 13 & 22.58 & 0.25 & 9-Tricosene, $(Z)-$ & $\mathrm{C}_{23} \mathrm{H}_{46}$ & 322 \\
\hline 14 & 23.075 & 0.47 & 15-Hydroxypentadecanoic acid & $\mathrm{C}_{15} \mathrm{H}_{30} \mathrm{O}_{3}$ & 258 \\
\hline 15 & 23.142 & 0.22 & cis-11-Eicosenoic acid, methyl ester & $\mathrm{C}_{21} \mathrm{H}_{40} \mathrm{O}_{2}$ & 324 \\
\hline 16 & 23.418 & 0.49 & Eicosanoic Acid, Methyl Ester & $\mathrm{C}_{21} \mathrm{H}_{42} \mathrm{O}_{2}$ & 326 \\
\hline 17 & 23.714 & 0.17 & 1-Glyceryl linoleate & $\mathrm{C}_{21} \mathrm{H}_{38} \mathrm{O}_{4}$ & 354 \\
\hline 18 & 24.49 & 0.47 & $\begin{array}{l}\text { 9,12-Octadecadienoic acid (Z, Z)-, 2-hydroxy- } \\
\text { 1-(hydroxymet }\end{array}$ & $\mathrm{C}_{21} \mathrm{H}_{38} \mathrm{O}_{4}$ & 354 \\
\hline 19 & 24.563 & 0.34 & Oleoyl chloride & $\mathrm{C}_{18} \mathrm{H}_{33} \mathrm{ClO}$ & 300 \\
\hline 20 & 25.141 & 1.37 & 9,12-Octadecadienoyl chloride, $(\mathrm{Z}, \mathrm{Z})$ - & $\mathrm{C}_{18} \mathrm{H}_{31} \mathrm{ClO}$ & 298 \\
\hline 21 & 25.214 & 1.02 & 9-Octadecenal, (Z)- & $\mathrm{C}_{18} \mathrm{H}_{34} \mathrm{O}$ & 266 \\
\hline 22 & 25.329 & 0.41 & 9,12-Octadecadienoyl chloride, $(\mathrm{Z}, \mathrm{Z})$ - & $\mathrm{C}_{18} \mathrm{H}_{31} \mathrm{ClO}$ & 298 \\
\hline 23 & 25.568 & 0.26 & Glycidol stearate & $\mathrm{C}_{21} \mathrm{H}_{40} \mathrm{O}_{3}$ & 340 \\
\hline 24 & 25.721 & 0.52 & Glycerol, 2-palmitate & $\mathrm{C}_{19} \mathrm{H}_{38} \mathrm{O}_{4}$ & 330 \\
\hline 25 & 25.961 & 0.64 & Docosanoic acid, methyl ester & $\mathrm{C} 2{ }_{3} \mathrm{H}_{46} \mathrm{O}_{2}$ & 354 \\
\hline 26 & 27.367 & 0.38 & .beta.-Eudesmol, trimethylsilyl ether & $\mathrm{C}_{18} \mathrm{H}_{34} \mathrm{OSi}$ & 294 \\
\hline 27 & 27.849 & 1.79 & Butyl 9,12-octadecadienoate & $\mathrm{C}_{22} \mathrm{H}_{40} \mathrm{O}_{2}$ & 336 \\
\hline 28 & 27.895 & 1.61 & Oleoyl chloride & $\mathrm{C}_{18} \mathrm{H}_{33} \mathrm{ClO}$ & 300 \\
\hline 29 & 28.268 & 0.31 & Tetracosanoic Acid, Methyl Ester & $\mathrm{C}_{25} \mathrm{H}_{50} \mathrm{O}_{2}$ & 382 \\
\hline 30 & 30.211 & 0.29 & Cholesta-3,5-diene & $\mathrm{C}_{27} \mathrm{H}_{44}$ & 368 \\
\hline 31 & 30.746 & 0.85 & 9,12 -Octadecadien-1-OL & $\mathrm{C}_{18} \mathrm{H}_{34} \mathrm{O}$ & 266 \\
\hline 32 & 31.607 & 4.72 & Ergost-4,7,22-trien-3.alpha.-ol & $\mathrm{C}_{28} \mathrm{H}_{44} \mathrm{O}$ & 396 \\
\hline 33 & 32.604 & 0.18 & $\begin{array}{l}\text { Cholesta-2,8-dien-6-ol, 14-methyl-, acetate, } \\
\text { 5.alpha., 6.alpha. }\end{array}$ & $\mathrm{C}_{30} \mathrm{H}_{48} \mathrm{O}_{2}$ & 440 \\
\hline 34 & 33.582 & 0.21 & Cholesterol & $\mathrm{C}_{27} \mathrm{H}_{46} \mathrm{O}$ & 386 \\
\hline 35 & 35.729 & 0.44 & Yohimban-16-Carboxylic Acid, 17-Hydroxy-, & $\mathrm{C}_{21} \mathrm{H}_{26} \mathrm{~N}_{2} \mathrm{O}_{3}$ & 354 \\
\hline 36 & 43.29 & 1.88 & 14-Methyl-8-Hexadecyn-1-Ol & $\mathrm{C}_{17} \mathrm{H}_{32} \mathrm{O}$ & :252 \\
\hline 37 & 51.989 & 3.69 & $\begin{array}{l}\text { Tricyclo[20.8.0.0(7, 16)] triacontane, } \\
1(22), 7(16) \text {-diepoxy- }\end{array}$ & $\mathrm{C}_{30} \mathrm{H}_{52} \mathrm{O}_{2}$ & 444 \\
\hline 38 & 53.385 & 0.97 & Tridecanedial & $\mathrm{C}_{13} \mathrm{H}_{24} \mathrm{O}_{2}$ & 212 \\
\hline
\end{tabular}




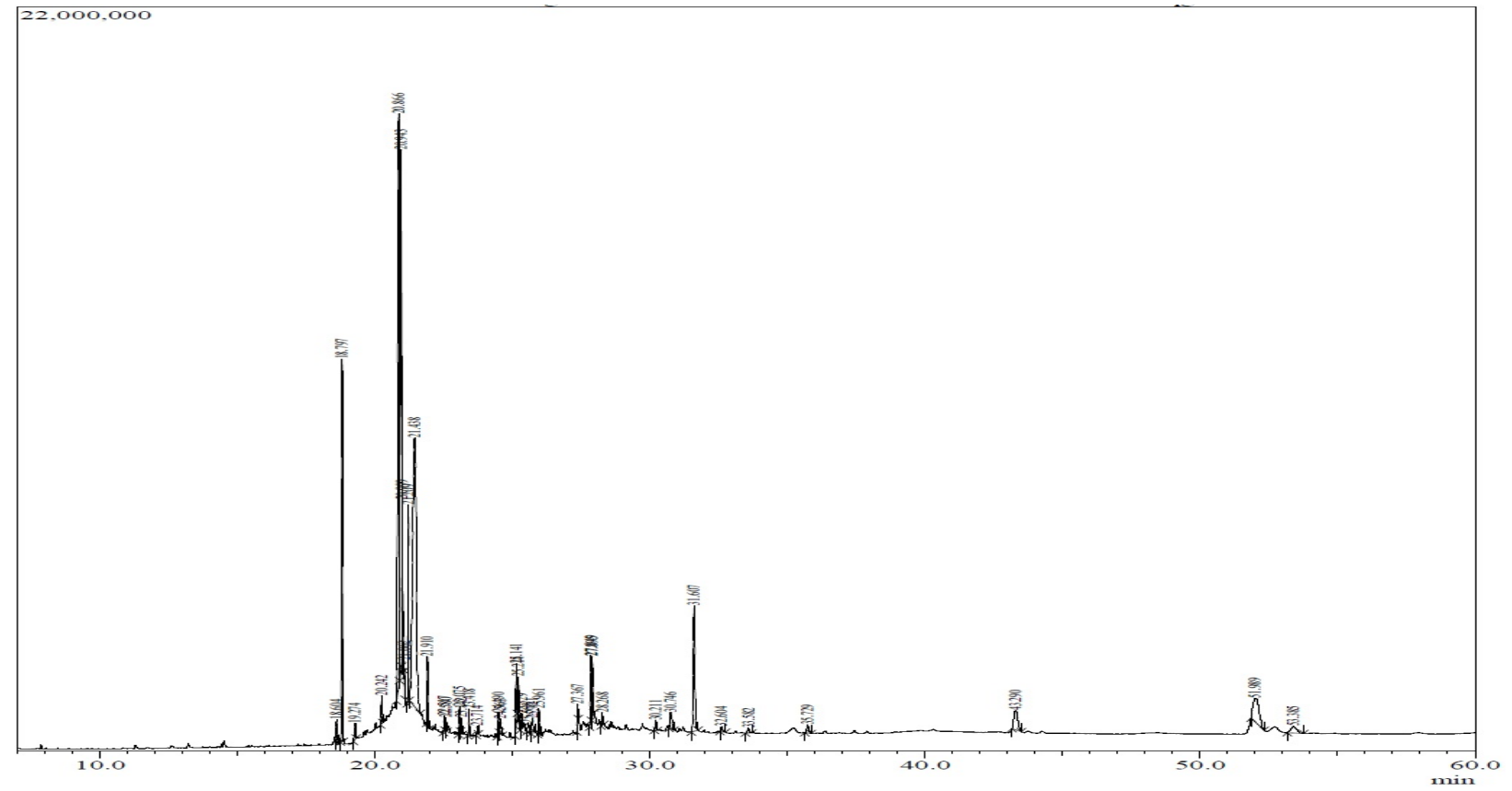

Figure 3 GC-MS analysis of methanolic extract of leaves of in vitro regenerated plant of $R$. serpentine. 

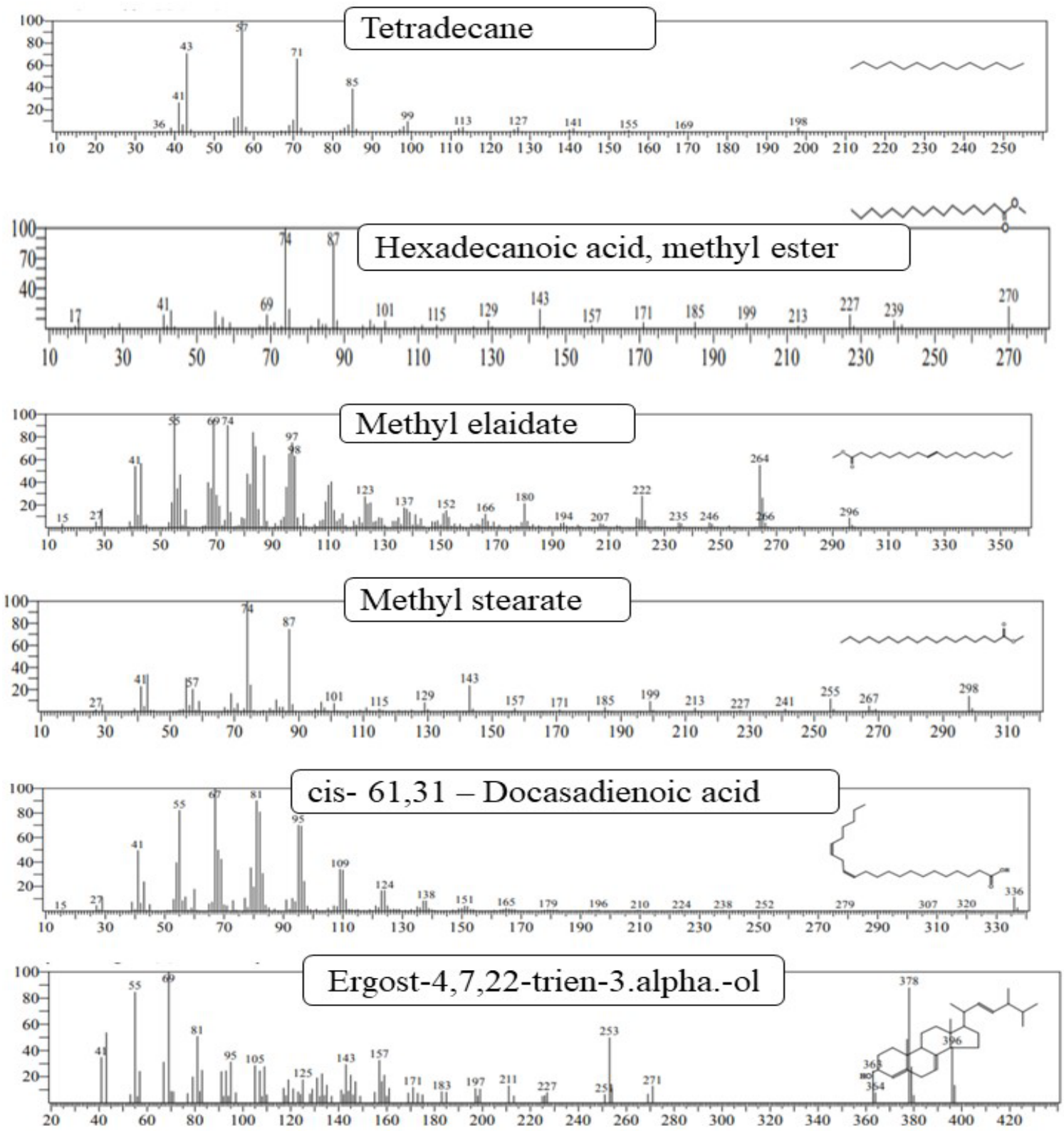

Figure 4 Mass spectra of selected compounds identified to be present in leaves of mother plant. 
http://wjst.wu.ac.th

Table 4 GC-MS analysis of methanolic extract of leaves of in vitro regenerated plant of $R$. serpentine.

\begin{tabular}{|c|c|c|c|c|c|}
\hline Peak & R. time & $\begin{array}{c}\text { Area } \\
\%\end{array}$ & Name of compound & Mol formula & $\begin{array}{c}\text { Mol } \\
\text { weight }\end{array}$ \\
\hline 1 & 11.311 & 0.32 & Tetradecane & $\mathrm{C}_{14} \mathrm{H}_{30}$ & 198 \\
\hline 2 & 14.404 & 0.27 & Heptadecane & $\mathrm{C}_{17} \mathrm{H}_{36}$ & 240 \\
\hline 3 & 16.145 & 0.13 & Methyl tetradecanoate & $\mathrm{C}_{15} \mathrm{H}_{30} \mathrm{O}_{2}$ & 242 \\
\hline 4 & 17.198 & 0.12 & Eicosane & $\mathrm{C}_{20} \mathrm{H}_{42}$ & 282 \\
\hline 5 & 18.525 & 0.32 & 9-hexadecenoic acid, methyl ester, (z)- & $\mathrm{C}_{17} \mathrm{H}_{32} \mathrm{O}_{2}$ & 268 \\
\hline 6 & 18.572 & 1.29 & 1-pentadecanamine, n,n-dimethyl- & $\mathrm{C}_{17} \mathrm{H}_{37} \mathrm{~N}$ & 255 \\
\hline 7 & 18.618 & 1.32 & 1-pentadecanamine, $n, n$-dimethyl- & $\mathrm{C}_{17} \mathrm{H}_{37} \mathrm{~N}$ & 255 \\
\hline 8 & 18.833 & 11.89 & Hexadecanoic acid, methyl ester & $\mathrm{C}_{17} \mathrm{H}_{34} \mathrm{O}_{2}$ & 270 \\
\hline 9 & 18.883 & 0.16 & 1,3-dimesityl-2-propen-1-one & $\mathrm{C}_{21} \mathrm{H}_{24} \mathrm{O}$ & 292 \\
\hline 10 & 19.317 & 0.38 & Pentadecanoic acid & $\mathrm{C}_{15} \mathrm{H}_{30} \mathrm{O}_{2}$ & 242 \\
\hline 11 & 20.029 & 0.17 & Heptadecanoic acid, methyl ester & $\mathrm{C}_{18} \mathrm{H}_{36} \mathrm{O}_{2}$ & 284 \\
\hline 12 & 20.266 & 0.21 & Hexadecanoic acid, trimethylsilyl ester & $\mathrm{C}_{19} \mathrm{H}_{40} \mathrm{O}_{2} \mathrm{Si}$ & 328 \\
\hline 13 & 20.337 & 0.08 & Hexahydrocyclobuta[c]pentalen-3-one & $\mathrm{C}_{10} \mathrm{H}_{14} \mathrm{O}$ & 150 \\
\hline 14 & 20.918 & 24.35 & Cis-Linoleic Acid Methyl Ester & $\mathrm{C}_{19} \mathrm{H}_{34} \mathrm{O}_{2}$ & 294 \\
\hline 15 & 21.003 & 15.34 & Methyl elaidate & $\mathrm{C}_{19} \mathrm{H}_{36} \mathrm{O}_{2}$ & 296 \\
\hline 16 & 21.05 & 7.66 & Linoleic acid, methyl ester & $\mathrm{C}_{19} \mathrm{H}_{34} \mathrm{O}_{2}$ & 294 \\
\hline 17 & 21.24 & 4.5 & Methyl stearate & $\mathrm{C}_{19} \mathrm{H}_{38} \mathrm{O}_{2}$ & 298 \\
\hline 18 & 21.474 & 15.28 & Grape seed oil/ linoleic acid & $\mathrm{C}_{18} \mathrm{H}_{32} \mathrm{O}_{2}$ & 280 \\
\hline 19 & 21.929 & 1.77 & 9,12-Octadecadienoic Acid, Methyl Ester & $\mathrm{C}_{19} \mathrm{H}_{34} \mathrm{O}_{2}$ & 294 \\
\hline 20 & 22.525 & 0.12 & Linoleoyl chloride & $\mathrm{C}_{18} \mathrm{H}_{31} \mathrm{ClO}$ & 298 \\
\hline 21 & 22.586 & 0.14 & 9-tricosene, $(z)-$ & $\mathrm{C}_{23} \mathrm{H}_{46}$ & 322 \\
\hline 22 & 23.082 & 0.27 & 15-hydroxypentadecanoic acid & $\mathrm{C}_{15} \mathrm{H}_{30} \mathrm{O}_{3}$ & 258 \\
\hline 23 & 23.149 & 0.25 & cis-11-eicosenoic acid, methyl ester & $\mathrm{C}_{21} \mathrm{H}_{40} \mathrm{O}_{2}$ & 324 \\
\hline 24 & 23.429 & 0.56 & Eicosanoic acid, methyl ester & $\mathrm{C}_{21} \mathrm{H}_{42} \mathrm{O}_{2}$ & 326 \\
\hline 25 & 24.503 & 0.28 & Linoleoyl chloride & $\mathrm{Cl}_{8} \mathrm{H}_{31} \mathrm{ClO}$ & 298 \\
\hline 26 & 24.57 & 0.11 & Oleoyl chloride & $\mathrm{C}_{18} \mathrm{H}_{33} \mathrm{ClO}$ & 300 \\
\hline 27 & 25.15 & 0.79 & 9,12-octadecadienoyl chloride, $(\mathrm{z}, \mathrm{z})$ - & $\mathrm{C}_{18} \mathrm{H}_{31} \mathrm{ClO}$ & 298 \\
\hline 28 & 25.224 & 0.6 & 9-octadecenal, (z)- & $\mathrm{C}_{18} \mathrm{H}_{34} \mathrm{O}$ & 266 \\
\hline 29 & 25.344 & 0.19 & 9,12-octadecadienoyl chloride, $(\mathrm{z}, \mathrm{z})$ - & $\mathrm{C}_{18} \mathrm{H}_{31} \mathrm{ClO}$ & 298 \\
\hline 30 & 25.577 & 0.11 & Glycidol stearate & $\mathrm{C}_{21} \mathrm{H}_{40} \mathrm{O}_{3}$ & 340 \\
\hline 31 & 25.736 & 0.42 & 1-Glycerol hexadecanoate & $\mathrm{C}_{19} \mathrm{H}_{38} \mathrm{O}_{4}$ & 330 \\
\hline 32 & 25.973 & 0.61 & Docosanoic acid, methyl ester & $\mathrm{C}_{23} \mathrm{H}_{46} \mathrm{O}_{2}$ & 354 \\
\hline 33 & 27.381 & 0.51 & Bornyl cinnamate & $\mathrm{C}_{19} \mathrm{H}_{24} \mathrm{O}_{2}$ & 284 \\
\hline 34 & 27.864 & 2.43 & Ethyl linoleate & $\mathrm{C}_{20} \mathrm{H}_{36} \mathrm{O}_{2}$ & 308 \\
\hline 35 & 28.275 & 0.15 & tetracosanoic acid, methyl ester & $\mathrm{C}_{25} \mathrm{H}_{50} \mathrm{O}_{2}$ & 382 \\
\hline 36 & 30.222 & 0.13 & Cholesteryl benzoate & $\mathrm{C}_{34} \mathrm{H}_{50} \mathrm{O}_{2}$ & 490 \\
\hline 37 & 30.761 & 0.38 & 9,12-octadecadien-1-ol & $\mathrm{C}_{18} \mathrm{H}_{34} \mathrm{O}$ & 266 \\
\hline 38 & 31.618 & 2.05 & Ergost-4,7,22-trien-3.alpha.-ol & $\mathrm{C}_{28} \mathrm{H}_{44} \mathrm{O}$ & 396 \\
\hline 39 & 43.328 & 1.03 & (14Z)-14-Tricosenyl Formate & $\mathrm{C}_{17} \mathrm{H}_{32} \mathrm{O}$ & 252 \\
\hline 40 & 52.06 & 2.75 & $\begin{array}{l}\text { Tricyclo[20.8.0.0(7,16)] triacontane, } 1(22), 7(16)- \\
\text { diepoxy- }\end{array}$ & $\mathrm{C}_{30} \mathrm{H}_{52} \mathrm{O}_{2}$ & 444 \\
\hline 41 & 53.461 & 0.54 & Tridecanedial & $\mathrm{C}_{13} \mathrm{H}_{24} \mathrm{O}_{2}$ & 212 \\
\hline
\end{tabular}



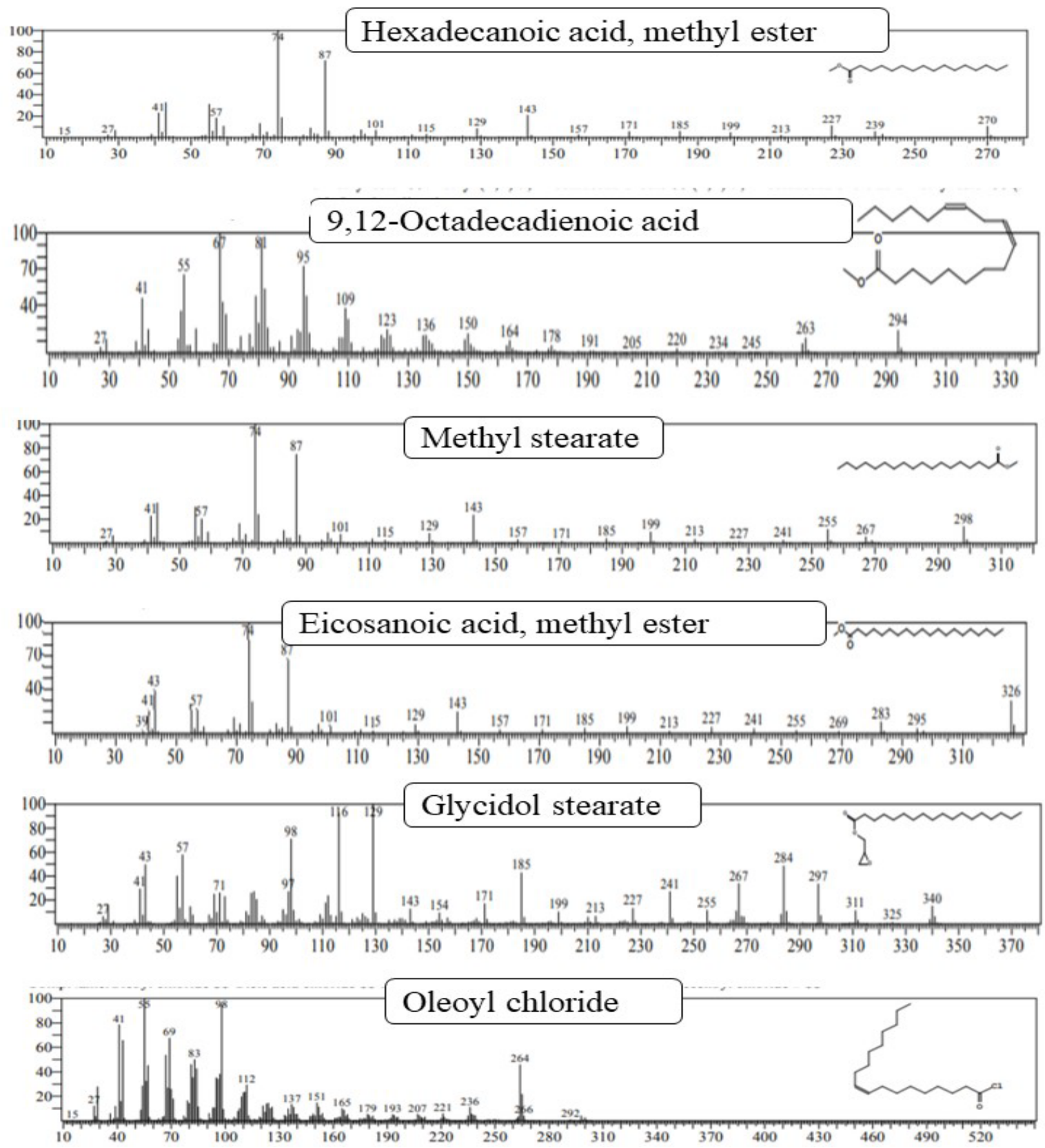

Figure 5 Mass spectra of selected compounds identified to be present in leaves of micropropagated plant. 
http://wjst.wu.ac.th

Table 5 Biological activities (reported in literature) of selected phytocompounds found to be present in leaves of $R$ serpentina.

\begin{tabular}{llc}
\hline Name of phytocompound & \multicolumn{1}{c}{ Biological properties } & Author / Reference \\
\hline Methyl stearate & Antidiarrheal, cytotoxic, antiproliferative activities & {$[32,33]$} \\
Eicosane & Anti-tumor, antimicrobial activities & {$[34,35,36]$} \\
Esters of octadecanoic acid & Antimicrobial, antioxidant activities & {$[32]$} \\
Methyl elaidate & Potential apoptotic agent & {$[37]$} \\
Methyl linoleate & Antifungal, antiproliferative properties & {$[38]$} \\
Methyl tetradecanoate & Antioxidant, cancer preventive, nematicidal, & {$[39]$} \\
& hypercholesterolemic activities & {$[39]$} \\
9, octadecanoic acid methyl ester & Anti-inflammatory, anti-cancer, antiandrogenic, 5- & \\
& alpha reductase activities & {$[40]$} \\
Linoleic acid & Antibacterial and antifungal activity & {$[36]$} \\
Linoleic acid, methyl ester & Antibacterial, anti-inflammatory, hepatoprotective & \\
Hexadecenoic acid, methyl ester & activities & Anti-inflammatory, antioxidant, antidiabetic, \\
& hypocholesterolemic activities & {$[35]$} \\
\hline
\end{tabular}

\section{Conclusions}

The present study reports a simple and effective method for the in vitro propagation of $R$. serpentine through micropropagation of apical parts, considering the apical part to possess meristematic tissue. Moreover, the presence of biologically active phytocompounds in the leaves of $R$. serpentine, as revealed by GC-MS analysis, supports the utilization of leaves for medicinal purposes, for which further studies are required for authentication and validation.

\section{Acknowledgements}

The authors are thankful to Dr. Manjul Dhiman, Head of the Department of Botany, Kanahiya Lal DAV (PG) College, Roorkee, India, for his support rendered in the authentication of mother plants of $R$. serpentina.

\section{References}

[1] A Rani, M Kumar and S Kumar. Effect of growth regulators on micropropagation of Rauvolfia serpentina (L.) Benth. J. Nat. Appl. Sci. 2014; 6, 507-11.

[2] S Chauhan, A Kaur and RK Pareek. Pharmacobotanical and pharmacological evaluation of Ayurvedic crude drug: Rauwolfia serpentina (Apocynaceae). Int. J. Green Pharm. 2017; 11, 68693.

[3] B Mitta, Meenakshi, A Sharma and V Gothecha. Phytochemical and pharmacological activity of Rauwolfia serpentina-A review. Int. J. Ayurvedic. Herb. Med. 2012; 2, 427-34.

[4] GS Panwar, IH Attitalla and SK Guru. An efficient in vitro clonal propagation and estimation of reserpine content in different parts of Rauwolfia serpentina L. American-Eurasian J. Sci. Res. 2011; 6, 217-22.

[5] KK Pant and SD Joshi. Rapid multiplication of Rauvolfia serpentina Benth.ex. Kurz through tissue culture. Sci. World. J. 2008; 6, 58-62.

[6] M Singh, R Kaur, R Rajput and G Mathur. Evaluating the therapeutic efficiency and drug targeting ability of alkaloids present in Rauwolfia serpentine. Int. J. Green Pharm. 2017; 11, 132-42. 
http://wjst.wu.ac.th

[7] HK Singh, AA Charan, AI Charan and SM Prasad. Antifungal and Antibacterial activity of methanolic, ethanolic and acetonic leaf extracts of Sarpagandha (Rauwolfia serpentina). Int. J. Pharmacol. Phytochem. Ethnomed. 2017; 6, 152-6.

[8] R Kumari, B Rathi, A Rani and S Bhatnagar. Rauvolfia serpentina L. Benth. Kurz.; Phytochemical, Pharmacological and therapeutic aspects. Int. J. Pharm. Sci. Rev. Res. 2013; 23, 348-55.

[9] SK Panda, D Das, BN Tripathy and L Nayak. Phyto-pharmacognostical studies and quantitative determination of reserpine in different parts of Rauwolfia (spp.) of Eastern Odisha by UV spectroscopy method. Asian J. Plant. Sci. Res. 2012; 2,151-62.

[10] A Itoh, T Kumashiro, M Yamaguchi, N Nagakura, Y Mizushina, T Nishi and T Tanahashi. Indole alkaloids and other constituents of Rauvolfia serpentine. J. Nat. Prod. 2005; 68, 848-52.

[11] A Dey and JN De. Rauvolfia serpentina (L). Benth. Ex Kurz.: A review. Asian J. Plant. Sci. 2010; 9, 285-98.

[12] SR Mallick, RC Jena and KC Samal. Rapid in vitro multiplication of endangered medicinal plant Sarpgandha (Rauwolfia serpentine). American J. Plant. Sci. 2012; 3, 437-42.

[13] V Chaudhary, Shalini and S Sharma. Direct in vitro regeneration from leaf segments of Rauwolfia serpentine. Int. J. Plant. Animal Environ. Sci. 2016; 6, 82-6.

[14] P Singh, A Singh, AK Shukla, L Singh, V Pande and TK Nailwal. Somatic embryogenesis and in vitro regeneration of an endangered medicinal plant Sarpgandha (Rauvolfia serpentine.L). Researcher 2009; 1, 46-53.

[15] T Susila, GS Reddy and D Jyothsna. Standardization of protocol for in vitro propagation of an endangered medicinal plant Rauwolfia serpentina Benth. J. Med. Plant Res. 2013; 7, 2150-3.

[16] TS Murashige and F Skoog. A revised medium for rapid growth and bioassays with tobacco tissue cultures. Plant Physiol. 1962; 15, 473-9.

[17] N Sharma, P Sachdeva, M Dhiman and EP Koshy. Comparative evaluation of in vitro regeneration potential of seeds of $W$. somnifera and $W$. coagulans. Biotechnol. Res. Int. 2015; 8, 21-33.

[18] PE Rajasekharan. Micropropagation of Rauvolfia serpentine: A potent endangered medicinal plant. Biomedicine 2010; 5, 74-9.

[19] S Khan, TA Banu, S Akter, B Goswami, M Islam, U Hani and A Habib. In vitro regeneration protocol of Rauvolfia serpentine L. Bangladesh J. Sci. Ind. Res. 2018; 53, 133-8.

[20] L Benth, U Salma, MSM Rahman, S Islam, N Haque, M Khatun, T Al-Jubair and BC Paul. Mass propagation of Rauwolfia serpentine. J. Biol. Sci. 2008. 11, 1273-7.

[21] I Ilahi, F Rahim and M Jabeen. Enhanced clonal propagation and alkaloid biosynthesis in cultures of Rauwolfia. Pak. J. Plant Sci.2007; 13, 45-56.

[22] V Chaudhary, S Singh, S Vaid and N Sharma. In vitro regeneration of Rauwolfia serpentina through another culture studies. Biotechnol. Res. Int. 2015; 8, 93-100.

[23] RN Bahuguna, R Joshi, G Singh, A Shukla, R Gupta and G Bains. Micropropagation and total alkaloid extraction of Indian snake root (Rauwolfia serpentina): An important antihypersensitive medicinal shrub. Indian J. Agric. Res. 2011; 81, 1124-9.

[24] A Hussain, PB Neupane and RN Jha. Phytochemical and GC-MS analysis of n-Hexane extract of Rauvolfia serpentina L. Benth. Ex Kurz. Chem Sci Rev Lett. 2015; 4, 223-9.

[25] T Sivaraman, NS Sreedevi and S Meenatchisundaram. Phytochemical and GC-MS analysis of ethanolic extract of Rauwolfia serpentina root. Eur. J. Pharm. Med. Res. 2017; 4, 646-50.

[26] K Rajkumar and R Malathi. Phytochemical investigation GC-MS analysis and in vitro antimicrobial activity of Coleus forskohlii. Bangladesh J. Pharmacol. 2015; 10, 924-30.

[27] J Patel, R Venkateshwar, GS Kumar, D Satyasai and B Bajari. Gas chromatography and mass spectroscopy analysis of bioactive components on the leaf extract of Terminalia coriacea: A potential folklore medicinal plant. Int. J. Green Pharm. 2017; 11, 8140-3.

[28] MS Rukshana, A Doss and PR Kumari. Phytochemical Screening and GC-MS analysis of leaf extract of Pergularia daemia (Forssk) Chiov. Asian J. Plant Sci. Res. 2017; 7, 9-15. 
http://wjst.wu.ac.th

[29] I Rautela, MD Sharma, N Sharma, K Kishor, K Singh and N Sharma. Comparative GC-MS analysis of leaf and root extract of medicinal plant Withania somnifera. World J. Pharm. Res. 2018; 7, 95672.

[30] N Sharma, I Rautela and MD Sharma. Mass propagation and GC-MS analysis of critically endangered plant Withania coagulans. Int. J. Appl. Pharm. Bio Tech. 2016; 7, 62-70.

[31] AVP Karthikeyan and I Sudan. GC-MS profile of in vivo and in vitro shoots of Cleome gynandra L. Int. J. Pharm. Sci. Res. 2017; 9, 21-6.

[32] N Mulyono, BW Lay, L Ocktreya and S Rahayu. Antidiarrheal activity of apus Bamboo (Gigantochloa apus) leaf Extract and its bioactive compounds. American J. Microbiol. 2013; 4, 1-8.

[33] Turatti, BC Avalcanti, LV Costa-Lotufo, C Pessoa, MO de Moraes, V Manfrim, JS Toledo, AK Cruz and MT Pupo. Bioactive extracts and chemical constituents of 2 endophytic strains of Fusarium oxysporum. Rev. Bras. Farmacogn. 2012; 22, 1276-12.

[34] FR Yu, XZ Lian, HY Guo, PM McGuire, RD Li, R Wang and FH Yu. Isolation and characterization of methyl esters and derivatives from Euphorbia kansui (Euphorbiaceae) and their inhibitory effects on the human SGC-7901 cells. J. Pharm. Pharm. Sci. 2005; 8, 528-35.

[35] PS Prajna, R Bhat and S Kumar. Identification of bioactive compounds in Loeseneriella arnottiana wight root by GC-MS analysis. World J. Pharm. Res. 2016; 5, 1559-69.

[36] P Godara, BK Dulara, N Barwer and NS Chaudhary. Comparative GC-MS Analysis of Bioactive Phytochemicals from different plant parts and callus of Leptadenia reticulate Wight and Arn. Pharmacogn. J. 2019; 11, 129-40.

[37] IA Adebayo, H Arsad and MR Samian. Methyl elaidate: A major compound of potential anticancer extract of Moringa oleifera seeds binds with bax and MDM2 (p53 inhibitor) In silico. Phcog. Mag. 2018; 14, 554-7.

[38] EAP Maria, GA Sthéfane, IM Marcela, PS Nívea, ML Caroline, AR Carlos, PS Ezequias, J Susana and ARS Luciana. Antifungal and antioxidant activity of fatty acid methyl esters from vegetable oils. An. Bras. Acad. Sci. 2017; 89, 1671-81.

[39] A Elaiyaraja and G Chandramohan. Comparative phytochemical profile of crinum defixum KerGawler leaves using GC-MS. J. Drug Deliv. Ther. 2018; 8, 365-80.

[40] G Agoramoorthy, M Chandrasekaran, V Venkatesalu and MJ Hsu. Antibacterial and antifungal activities of fatty acid methyl esters of the blind-your-eye mangrove from India. Braz. J. Microbiol. 2007; 38, 739-42. 